\title{
Are Teacher Education Programs Attractíng Academically Able Students?
}

HE recognized professions have for decades attracted many academically able youth to the institutions charged with the responsibility for their preservice professional programs. Their ability to attract capable persons has without doubt substantially contributed to the esteem in which many of these professions are held by the public they serve. Conversely, it has often been asserted that one major reason for the low esteem in which teaching is held by the public is the well-established custom of permitting almost any college enrollee to pursue the program of teacher preparation in many teacher education institutions.

Many professional educators have long thought that this lack of concern for the quality of prospective candidates for graduation from teacher education programs is perhaps one of the more significant weaknesses of the total preservice program. Recently developed accrediting programs for teacher education at the national level, however, appear to be placing emphasis on the presence of wellconceived arrangements for selective admission to and retention in teacher education programs as a basis for accreditation. This concern, plus the general movement to strengthen certificating or licensing standards, has contributed to the improvement of teacher education programs in many institutions.

A study was completed in 1958 on the University of Oklahoma campus which involved 348 University of Oklahoma 1956 graduates who had entered that institution as freshmen in 1952. This study did not consider teacher education as a separate professional program, but compared only college programs in the University. The results, however, showed that those graduates preparing to teach performed at a significantly lower level than the students enrolled in the Colleges of Engineering, Business Administration, Pharmacy, and other professional programs in the University.

The contention has been made in recent years, however, that the quality of teacher education enrollees has improved on the University of Oklahoma campus. Like most teacher education institutions the University of Oklahoma had a selection program in 1959 based chiefly upon the candidate's ability to survive the academic competition during the first year of collegiate work and emerge from the University College, in which all freshmen enroll for approximately a year's work, with the required grade-point average. Specifically, entry into various colleges could not occur until a minimum of twenty-six hours of work in the University College was completed with a $\mathrm{C}$ average or better. This practice insured that the students who were most academically unfit would generally not gain admittance to teacher education or any other professional program. In the absence of a carefully planned program of selective admission and retention it

Dr. Snider is professor of education and Mr. Long is a graduate assistant at the College of Education, University of Oklahoma, Norman. 
was at least possible, therefore, to know that most of the prospective teachers were students of average or above average academic ability. The same major factor of academic performance which characterized eligibility for the teacher education program at the University of Oklahoma was also operative for the Colleges of Engineering, Business Administration, and Pharmacy.

In order to gather more information concerning teacher education enrollees a study was conducted at the University of Oklahoma in 1959, with the specific objective of finding answers to the following questions:

1. Which professional undergraduate programs at the University of Oklahoma attracted the highest percentage of academically able students?

2. How did the students enrolled in the University of Oklahoma Teacher Education Program compare with those enrolled in other professional undergraduate programs of comparable length?

It was felt that answers to the above questions would give some indication of the quality of students enrolled in the preservice program for the preparation of teachers at the University of Oklahoma. Was this program actually attracting students who were generally inferior in academic ability to those enrolled in other professional programs or was it attracting its share of able students?

The study attempted to compare students enrolled in the following four professional programs at the University of Oklahoma: the College of Engineering, the College of Business Administration, the College of Pharmacy, and the Teacher Education Program. For clarity and consistency the College of Business Administration, the College of Engineering, the College of Pharmacy and the Teacher Education Program were referred to as professional programs. It was recognized that several different pro- fessional programs existed in both the College of Engineering and the College of Business Administration, but they were all categorized as single professional programs. The Teacher Education Program was also considered to be a single professional program even though teaching certificate programs were completed in eighteen fields and degrees were earned in any one of three colleges: Education, Arts and Sciences, and Fine Arts.

\section{Criteria}

It was necessary to establish criteria for the determination of academic ability. The grade-point average often had been used as a criterion in ascertaining the academic proficiency of the college student, but this criterion was ignored because the academic standards of the various professional programs within a university often differ significantly and because this criterion is dependent upon the subjective judgments of college professors. Since the purpose of the study was to compare the academic ability of the senior students enrolled in professional programs in Business, Engineering, Teacher Education, and Pharmacy, it was assumed that an analysis of these students' performances on the Ohio State University Psychological Examination, the Iowa High School Content Examination, and the University of Oklahoma Mathematics Placement Examination would provide reliable data for a comparative study. For these reasons the study was limited to an analysis of the scores of senior students enrolled in the four professional programs on the three examinations described above.

It should be noted that only nontransfer students-those who began their programs at the University of Oklahoma -were included in the study. Transfer students were not included because they did not take the placement examinations. Five hundred and thirty students were included in the study, including 191 
TABLE I

Frequency Distribution Percentages

on the Ohio State University Psychological Examination By Professional Program

\begin{tabular}{lrrrrrrrrrrrr}
\hline & Total No. & \multicolumn{7}{c}{ Percentages of Students by Decile } \\
\cline { 2 - 12 } \multicolumn{1}{c}{ Professional Program } & Students & 1 & 2 & 3 & 4 & 5 & 6 & 7 & 8 & 9 & 10 \\
\hline Business Administration & 191 & 14 & 17 & 11 & 10 & 19 & 10 & 8 & 6 & 5 & 0 \\
Engineering & 158 & 10 & 6 & 8 & 9 & 15 & 11 & 20 & 9 & 12 & - \\
Pharmacy & 23 & 9 & 9 & 22 & 22 & 0 & 9 & 13 & 12 & 4 & 0 \\
Teacher Education & 158 & 12 & 15 & 9 & 9 & 18 & 9 & 6 & 8 & 8 & 6 \\
\hline
\end{tabular}

seniors in Business Administration, 158 in Engineering, 158 in the Teacher Education Program and 23 in Pharmacy.

\section{Examination Performances}

The Ohio State University Psychological Examination, Form 23, is designed to measure scholastic aptitude, which is one aspect of general intelligence. The test was published as a power-type test; it is widely used and has been utilized as a basis for considerable research since the first form was constructed in 1920 . It was administered to all beginning freshmen as a part of the examination program.

High performance on this test was considered by all four professional programs as indicative of probable academic success in their programs. The results of this examination disclosed some obvious differences between the performances of the students in the two professional programs scoring highest and lowest, Engineering and Business Administration, respectively. The only students scoring at the tenth decile were those in the Teacher Education Program, while the largest percentage of students scoring at the ninth decile were enrolled in the Engineering Program. The Teacher Education Program led in the percentage of students whose scores fell into the upper three deciles followed by the Engineering, Pharmacy, and Business Administration Programs in that order. The highest percentage of students falling into the first three deciles was from the Business Administration Program, followed in order by Pharmacy, Teacher Education, and Engineering.

The Iowa High School Content Examination measured general scholastic aptitude in the four areas of English, history, mathematics, and science and was a part of the examination program administered to all entering freshmen at the University of Oklahoma. Individual test scores are derived. The test is useful in two ways: (1) it measures student achievement and mastery of secondary school subjects and (2) it provides information for guidance and prognostic purposes at the college or university level.

Again only students enrolled in the Teacher Education Program scored at the tenth decile on this examination. The largest percentage of students scoring at the ninth decile were enrolled in the College of Pharmacy. This same program had the highest percentage of students falling into the upper three deciles, followed by Engineering, Teacher Education, and Business Administration, in that order. The Teacher Education Program had the highest percentage of students in the lower three deciles followed by Engineering and Business Administration in second position with Pharmacy showing the smallest percentage in this category.

It was assumed that engineering students should probably make a higher score on the Oklahoma University 
TABLE II

Frequency Distribution Percentages on the Iowa High School Content Examination by Professional Program

\begin{tabular}{|c|c|c|c|c|c|c|c|c|c|c|c|}
\hline \multirow[b]{2}{*}{ Professional Program } & \multirow{2}{*}{$\begin{array}{c}\text { Total No. } \\
\text { of } \\
\text { Students }\end{array}$} & \multicolumn{10}{|c|}{ Percentages of Students by Decile } \\
\hline & & 1 & 2 & 3 & 4 & 5 & 6 & 7 & 8 & 9 & 70 \\
\hline Business Administration & 191 & 18 & 9 & 10 & 13 & 10 & 10 & 12 & 8 & 10 & 0 \\
\hline Engineering & 158 & 28 & 3 & 6 & 9 & 6 & 9 & 13 & 9 & 17 & 0 \\
\hline Pharmacy & 23 & 13 & 9 & 9 & 13 & 0 & 13 & 13 & 9 & 21 & 0 \\
\hline Teacher Education & 158 & 11 & 15 & 18 & 8 & 6 & 11 & 9 & 6 & 8 & 8 \\
\hline
\end{tabular}

Mathematics Placement Examination than students in the other programs since exceptional skill in mathematics is essential to success in engineering. Proficiency in mathematics is also important in the business and pharmacy programs but is not generally considered essential for all teacher education students.

The results of this test, developed at the University of Oklahoma, tended to substantiate these assumptions. Engineering students scored higher than students in the other programs which ranked in order as follows: Pharmacy, Business Administration, and Teacher Education. The Teacher Education Program had a smaller percentage of students performing above the university mean than any other program and also a higher percentage performing below the mean.

\section{General Conclusions}

Many other elements not measured by any of these tests are probably important to the success of the practitioners produced by each program. If the assumptions are made that academic ability is relevant to success in teaching and that tests used at the University of Oklahoma measure such specific and general academic abilities, the results indicated that the quality of prospective teachers in the Teacher Education Program at the University of Oklahoma compared favorably with that of students enrolled in some other professional programs.

With the exception of scores on the Oklahoma University Mathematics Place- ment Test, on which engineering students scored higher than students in the other professional programs, the results of the Ohio State University Psychological Examination and the Iowa High School Content Examination suggested that the performance of students on these two tests did not differ greatly in the four programs. The results of the last two tests showed that all four professional programs were graduating approximately an equal percentage of students of apparently similar academic ability. It may be stated with more assurance that the College of Engineering had attracted students of higher mathematical proficiency than the other programs and that students in the Teacher Education Program compared favorably with those in the other professional programs except in mathematical proficiency. Students in Business Administration performed below those in Teacher Education on both the Ohio State University Psychological Examination and the Iowa High School Content Examina. tion.

The results of this study tended to substantiate the view held by many of the University of Oklahoma staff that the quality of teacher education enrollees in terms of academic ability improved in recent years and that the program enrolls many excellent students. Refutation or further substantiation of this belief can come from an analysis of future graduating classes.

These findings in no sense, however, reduce the responsibility of teacher edu- 
TABLE III

Prrcentages of Subjects Scoring Below, At, and Above the University Mean Score ON THE Oklahoma University Mathematics Examination

\begin{tabular}{lcccc}
\hline \multicolumn{1}{c}{ Professional Program } & Mean Score & $\begin{array}{c}\text { Per Cent } \\
\text { Below Mean }\end{array}$ & $\begin{array}{c}(x=12) \\
\text { At Mean }\end{array}$ & $\begin{array}{c}\text { Per Cent } \\
\text { Above Mean }\end{array}$ \\
\hline Business Administration & 14.74 & 35 & 25 & 40 \\
Engineering & 22.20 & 11 & 14 & 75 \\
Pharmacy & 15.35 & 30 & 26 & 44 \\
Teacher Education & 11.37 & 43 & 31 & 26 \\
\hline
\end{tabular}

cation institutions for establishing defensible selective admission and retention arrangements to insure quality in their graduates. Reliance on the normal mortality rate as the exclusive element in selective admission and retention assumes that academic proficiency is the only significant determinant of success in teaching. This assumption is obviously untenable.

MAJOR REASONS FOR LEAVING TEACHING GIVEN BY EX-TEACHERS AND SOURCES OF DISSATISFACTION AND FRUSTRATION FOR MEN STILL IN TEACHING

(Percent of respondents checking items)

\begin{tabular}{|c|c|c|c|c|}
\hline \multirow[b]{2}{*}{ Item } & \multicolumn{2}{|c|}{ Men who left } & \multicolumn{2}{|c|}{ Men who are still in } \\
\hline & $\begin{array}{c}\text { Classroom } \\
\text { teaching }\end{array}$ & $\begin{array}{c}\text { College } \\
\text { teaching }\end{array}$ & $\begin{array}{c}\text { Classroom } \\
\text { teaching }\end{array}$ & $\begin{array}{c}\text { College } \\
\text { teaching }\end{array}$ \\
\hline 1 & 2 & 3 & 4 & 5 \\
\hline Too many duties other than actual teaching. .... & $11.3 \%$ & $16.0 \%$ & $34.9 \%$ & $23.8 \%$ \\
\hline Didn't (don't) really like classroom teaching. . . . . & 8.2 & 8.0 & 0.4 & 1.3 \\
\hline School-board and community interference. . & 5.4 & 4.0 . & 10.1 & 2.6 \\
\hline Principal or supervisor was (is) difficult to work with & 11.0 & 4.0 & 7.9 & 5.1 \\
\hline Pay was (is) too low $\ldots \ldots \ldots \ldots \ldots \ldots \ldots \ldots$ & 66.7 & 59.3 & 44.6 & 38.8 \\
\hline I wasn't very good at teaching $\ldots \ldots \ldots \ldots$. & 2.7 & 4.0 & a & : \\
\hline Large classes and overcrowded rooms... & 9.5 & 4.0 & 33.6 & 22.8 \\
\hline Had chance at another good job. & 59.1 & 52.0 & - & - \\
\hline $\begin{array}{l}\text { Pupils not interested in learning, or disciplinary } \\
\text { problems................................. } \\
\text { Material and equipment for teaching were (are) }\end{array}$ & 8.7 & 4.0 & 25.7 & 11.7 \\
\hline lacking $\ldots \ldots \ldots \ldots \ldots \ldots \ldots \ldots \ldots$ & 5.4 & 0.0 & 14.6 & 11.5 \\
\hline No chance for promotion. & 24.8 & 20.0 & 11.8 & 10.3 \\
\hline $\begin{array}{l}\text { No intellectual stimulation.................... } \\
\text { Could (can) never get completely away from the }\end{array}$ & 10.9 & 4.0 & 5.0 & 3.8 \\
\hline 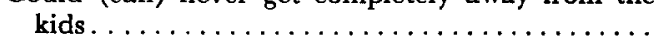 & 1.4 & 0.0 & 2.1 & 1.3 \\
\hline Found indoor work too confining $\ldots \ldots \ldots \ldots \ldots$ & 2.1 & 4.0 & - & . \\
\hline
\end{tabular}

Source:

Thorndike, Robert L., and Hagen, Elizabeth. "Men Teachers and Ex-Teachers: Some Attitudes and Traits." Teachers College Record 62: 306-16; January 1961. Tables 6 and 7, p. 312 and 314. Tables combined.

a Not applicable to men still in teaching.

- CEF Report, Committee on Educational Finance, National Education Association, Men Teachers and Men Ex-Teachers: Why Do So Many Good Teachers Leave Our Schools?'(Washington, D. C.: the Association, May, 1967) Number 3, p. 9. 